\title{
Hsp90 inhibitor BIIB021 enhances triptolide-induced apoptosis of human T-cell acute lymphoblastic leukemia cells in vitro mainly by disrupting p53- MDM2 balance
}

\author{
Min $\mathrm{LI}^{1}$, Xiang ZHANG ${ }^{2}$, Wen-jing ZHOU ${ }^{1}$, Yue-hua CHEN ${ }^{3}$, Hui LIU ${ }^{1}$, Lin LIU ${ }^{1}$, Chun-mei YANG ${ }^{1}$, Wen-bin QIAN ${ }^{1, *}$ \\ ${ }^{1}$ Institute of Hematology, the First Affiliated Hospital, College of Medicine, Zhejiang University, Hangzhou 310003, China; ${ }^{2}$ Department \\ of Hematology, Zhejiang Province Traditional Chinese Medicine Hospital, Hangzhou 310006, China; ${ }^{3}$ Department of Hematology, Sha- \\ oxing Second Hospital, Shaoxing 312000, China
}

\begin{abstract}
Aim: To investigate the effects of BIIB021, an inhibitor of heat shock protein 90 (Hsp90) alone or in combination with triptolide (TPL) on T-cell acute lymphoblastic leukemia (T-ALL) and the mechanisms of action.

Methods: Human T-ALL cells line Molt-4 was examined. The cell viability was measured using MTT assay. Apoptotic cells were studied with Hoechst 33258 staining. Cell apoptosis and cell cycle were analyzed using flow cytometry with Annexin V/PI staining and PI staining, respectively. The levels of multiple proteins, including Akt, p65, CDK4/6, p18, Bcl-2 family proteins, MDM2, and p53, were examined with Western blotting. The level of MDM2 mRNA was determined using RT-PCR.

Results: Treatment of Molt-4 cells with BIIB021 (50-800 nmol/L) inhibited the cell growth in a dose-dependent manner (the IC ${ }_{50}$ value was 384.6 and $301.8 \mathrm{nmol} / \mathrm{L}$, respectively, at 48 and $72 \mathrm{~h}$ ). BllB021 dose-dependently induced $\mathrm{G}_{0} / \mathrm{G}_{1}$ phase arrest, followed by apoptosis of Molt-4 cells. Furthermore, BIIB021 increased the expression of p18, decreased the expression of CDK4/6, and activated the caspase pathway in Molt-4 cells. Moreover, BlIB021 (50-400 nmol/L) dose-dependently decreased the phospho-MDM2 and total MDM2 protein levels, but slightly increased the phospho-p53 and total p53 protein levels, whereas TPL (5-40 nmol/L) dosedependently enhanced p53 activation without affecting MDM2 levels. Co-treatment with BIIB021 and TPL showed synergic inhibition on Molt-4 cell growth. The co-treatment disrupted p53-MDM2 balance, thus markedly enhanced p53 activation. In addition, the co-treatment increased the expression of Bak and Bim, followed by increased activation of caspase-9.

Conclusion: The combination of BIIB021 and TPL may provide a novel strategy for treating T-ALL by overcoming multiple mechanisms of apoptosis resistance.
\end{abstract}

Keywords: anticancer drug; BIIB021; triptolide; acute lymphoblastic leukemia; T-cell; Hsp 90; apoptosis; p53; MDM2; Bcl-2

Acta Pharmacologica Sinica (2013) 34: 1545-1553; doi: 10.1038/aps.2013.124; published online 18 Nov 2013

\section{Introduction}

T-cell acute lymphoblastic leukemia (T-ALL) is a highly aggressive hematological malignancy that accounts for $10 \%-$ $15 \%$ of pediatric and $25 \%$ of adult ALL cases ${ }^{[1]}$. Clinically, this disease is characterized by a large proliferation of $\mathrm{T}$ cell lymphoblasts, high white blood cell counts, and extramedullary infiltration of the mediastinum and central nervous system. Although a high remission rate or even cure in over $75 \%$ in children and approximately $50 \%$ in adults can be achieved by applying intensive chemotherapy, primary drug resistance

\footnotetext{
* To whom correspondence should be addressed.

E-mail qianwenb@hotmail.com

Received 2013-05-01 Accepted 2013-08-02
}

and relapsed leukemia remain troubling issues for clinicians ${ }^{[2]}$. Therefore, the exploration of new therapeutic targets and agents, particularly those possessing a higher selectivity for tumor cells and less toxicity to normal tissues, is necessary for improving patient outcomes.

The overexpression of heat shock protein 90 (Hsp90) in ALL cells has been confirmed by several studies and is associated with the active and indefinite proliferation of leukemia cells $^{[3-5]}$. Moreover, Hsp90 inhibitors induce apoptosis in Philadelphia chromosome-positive ALL cells with a high sensitivity by increasing the degradation of BCR-ABL fusion proteins $^{[6,7]}$, a finding that has also been confirmed in chronic myeloid leukemia ${ }^{[8]}$. Considering the proliferative maintenance by Hsp90 overexpression in ALL, targeting Hsp90 may 
provide benefits to relapsed or refractory patients.

BIIB021 is the first fully synthetic Hsp90 inhibitor to enter clinic use for the treatment of solid tumors and hematological malignancies, such as B-cell chronic lymphocytic leukemia, lymphomas, and HER2-advanced breast cancer ${ }^{[9,10]}$. By binding to the ATP-binding pocket of Hsp90, BIIB021 induces the degradation of Hsp90 client proteins, including HER-2, Akt, and Raf-1, and results in the inhibition of tumor growth ${ }^{[10]}$. In addition, BIIB021 was found to inhibit the growth of Hodgkin's lymphoma (HL) cells by depleting NF-kB activity and sensitizing the cells to natural killer cell-mediated cytotoxicity $^{[11]}$. Furthermore, it has been reported that combination therapy using BIIB021 plus radiotherapy or chemotherapy could benefit cancer treatment ${ }^{[12,13]}$. A recent phase II clinical trial ${ }^{[14]}$ shows that BIIB021 improves the outcomes of patients with gastrointestinal stromal tumors refractory to imatinib and sunitinib, thus demonstrating that this agent possesses a broad prospect for further clinical applications. Nonetheless, only a few studies have been conducted using leukemic cells.

Triptolide (TPL, with the molecular formula of $\mathrm{C}_{20} \mathrm{H}_{24} \mathrm{O}_{6}$ ) is the main active ingredient of Tripterygium wilfordii, a traditional Chinese medicine, which was originally used as an immunosuppressor to treat various autoimmune diseases, such as rheumatoid arthritis and systemic lupus erythematosus. Recently, it has been shown that TPL is cytotoxic to cancer cells due to its ability to induce apoptosis, cell cycle arrest, and anti-angiogenesis ${ }^{[15,16]}$, and TPL exhibits the ability to target multiple signaling pathways in hematological malignancy. It has been reported that TPL sensitizes acute myeloid leukemia (AML) cells to TRAIL-induced apoptosis via the downregulation of XIAP and a p53-mediated increase in the death receptor $\mathrm{DR} 5^{[17]}$, inhibits NF- $\mathrm{kB}$ reporter activity regulated by the TNF-TNFR1-TRADD-TRAF2-NIK-TAK1IKK pathway ${ }^{[18]}$, chemosensitizes leukemic cells through the inhibition of miR-21 and increased levels of PTEN ${ }^{[19]}$, increases intracellular adriamycin accumulation via the downregulation of P-glycoprotein ${ }^{[20]}$, and triggers the degradation of AML1ETO fusion protein in $\mathrm{t}(8 ; 21)$-positive AML to suppress JAK/ STAT signaling and NF- $\mathrm{kB}$ activity ${ }^{[21]}$. The antileukemic activity of TPL has also been demonstrated in ALL cells ${ }^{[22]}$. We previously reported that TPL is an effective therapeutic agent for the treatment of T-ALL and that its cytotoxic effects are related to the suppression of NF-KB activity and miR-16-1* expression $^{[23]}$. However, the mechanisms of action of TPL in T-cell ALL remain elusive.

In this study, we focused on the therapeutic effects of the Hsp90 inhibitor BIIB021 and TPL alone and in combination on T-ALL in vitro and examined the underlying mechanisms.

\section{Materials and methods}

Cell culture and reagents

The human T-cell ALL cell line Molt-4 was purchased from the American Type Culture Collection (ATCC, Rockville, MD, USA), and the L-02 cell line, a normal human liver cell line, was purchased from the Shanghai Cell Collection (Shanghai, China). The cells were cultured in RPMI-1640 medium (Gibco,
Grand Island, NY, USA) with 10\% fetal bovine serum (Gibco) at $37^{\circ} \mathrm{C}$ in a humidified atmosphere of $5 \% \mathrm{CO}_{2}$. BIIB021 was purchased from Selleck Chemical Company (Houston, TX, USA), and triptolide (purity $>99 \%$ by HPLC) was purchased from Sigma-Aldrich (St Louis, MO, USA). The caspase inhibitors z-IETD-fmk and LEHD-fmk were purchased from Biovision (Palo Alto, CA, USA).

\section{Growth inhibition assay}

MTT assays were performed to evaluate the anti-ALL effects of BIIB021, TPL, and their co-treatment (BIIB021 at 25, 50, 100 , and $200 \mathrm{nmol} / \mathrm{L}$ combined with TPL at 5, 10, 20, and 40 $\mathrm{nmol} / \mathrm{L}$, respectively). In brief, Molt- 4 cells were cultured in a 96-well plate at a density of $5 \times 10^{4}$ and treated with or without the drugs. Then, $20 \mu \mathrm{L}$ of 3-(4,5-dimethylthiazol-2-yl)2,5-diphenyltetrazoliumbromide (MTT; Sigma) solution (5 $\mathrm{mg} / \mathrm{mL}$ ) was added to each well, and the cells were further incubated for $4 \mathrm{~h}$. The supernatant was removed, followed by the addition of $200 \mu \mathrm{L}$ of dimethyl sulfoxide (Amresco, Solon, OH, USA). The absorbance at a wavelength of $570 \mathrm{~nm}$ was detected using an enzyme-linked immunosorbent assay (ELISA) plate reader. Each assay was performed three times in triplicate.

\section{Hoechst DNA staining}

To detect morphological changes after treatment with BIIB021 $(100 \mathrm{nmol} / \mathrm{L})$ and TPL (20 nmol/L) alone and in combination, the cells were fixed with $4 \%$ formaldehyde for $30 \mathrm{~min}$, followed by $1 \mu \mathrm{g} / \mathrm{mL}$ Hoechst33258 (Sigma) staining at $37^{\circ} \mathrm{C}$ for 15 min. After washing with PBS, the slides were viewed by fluorescence microscopy using an excitation wavelength of 350 $\mathrm{nm}$ and an emission wavelength of $460 \mathrm{~nm}$.

\section{Annexin $\mathrm{V}$ and propidium iodide $(\mathrm{PI})$ staining}

Cells were cultured at a density of $5 \times 10^{4}$ in a 6-well plate and treated for $24 \mathrm{~h}$ with BIIB021 (50-800 nmol/L). The cells then were trypsinized and washed once with PBS. Aliquots of the cells were resuspended in $100 \mu \mathrm{L}$ of binding buffer and stained with $5 \mu \mathrm{L}$ of Annexin V-FITC and $1 \mu \mathrm{L}$ of PI working solution $(100 \mu \mathrm{g} / \mathrm{mL}$; Biouniquer, Suzhou, China) for $15 \mathrm{~min}$ in the dark. The cells were examined by flow cytometry, and the data acquisition and analyses were performed using a FACSCalibur flow cytometer (Becton-Dickinson, Franklin Lakes, NJ, USA) with CELLQuest software (Becton-Dickinson).

\section{Cell cycle analysis}

Molt- 4 cells cultured with BIIB021 at the indicated doses were harvested, fixed with $70 \%$ ethanol, and pretreated with 250 $\mu \mathrm{g} / \mathrm{mL}$ RNase A. The cells were then stained with PI (50 $\mu \mathrm{g} / \mathrm{mL}$; Sigma), and the cell cycle profile was determined by FACS.

\section{Western blot analysis}

Cells treated with PBS, BIIB021, TPL, or combinations were harvested at $24 \mathrm{~h}$ after treatment and subjected to a Western blot analysis, as described previously ${ }^{[23]}$. All the antibodies 
used in this study were purchased from Cell Signaling (Beverly, MA, USA), except for the human anti- $\beta$-actin (Sigma) antibody.

\section{Real-time RT-PCR}

Total RNA was obtained from Molt-4 cells treated with or without BIIB021 (400 nmol/L) for the indicated times using TRIzol reagent (Invitrogen, Carlsbad, CA, USA), and firststrand synthesis was performed using the SuperScript ${ }^{\mathrm{TM}}$ firststand system (Invitrogen) according to the manufacturer's instructions. The PCR assays were performed using the iQ5 thermal cycling system (Bio-Rad Laboratories, Hercules, CA, USA) with SYBR Green (TAKARA, Shimogyo-ku, Japan). The following specific primers were used to amplify MDM2 (5'-CATTGAACCTTGTGTGATTTGTC-3' /5'-GCAGGGCTTATTCCTTTTCTTTA-3') and GAPDH (5'-ATGGGGAAGGTGAAGGTCG-3' / 5'-GGGTCATTGATGGCAACAATATC-3'). The PCR reaction consisted of denaturation at $95^{\circ} \mathrm{C}$ for $1 \mathrm{~min}$, followed by 40 cycles of $5 \mathrm{~s}$ at $95^{\circ} \mathrm{C}$ and $30 \mathrm{~s}$ at $60^{\circ} \mathrm{C}$.

\section{Statistical analysis}

The experimental results are statistically presented as the mean $\pm S D$. The data were analyzed by a one-way analysis of variance (ANOVA), and a statistically significant difference was determined at $P<0.05$. The combination index (CIN) was analyzed using CalcuSyn software (Biosoft, Cambridge, UK), where $\mathrm{CIN}<0$ indicated synergy; $\mathrm{CIN}=0$ indicated an additive effect; and CIN $>0$ indicated antagonism.

\section{Results}

\section{BIIB021 inhibits the proliferation of Molt-4 cells}

To determine the effects of BIIB021 on the growth of Molt-4 cells, we treated the cells with BIIB021 at different concentrations and assessed cell proliferation using an MTT assay. As shown in Figure 1A, BIIB021 effectively inhibited Molt- 4 cell growth in a dose- and time-dependent manner. The 50\% inhibitory concentration $\left(\mathrm{IC}_{50}\right.$ ) values of BIIB021 were 384.6 $\mathrm{nmol} / \mathrm{L}$ at $48 \mathrm{~h}$ and $301.8 \mathrm{nmol} / \mathrm{L}$ at $72 \mathrm{~h}$. We next assessed changes in the cell cycle that occurred after treatment of Molt-4 cells with BIIB021 for $24 \mathrm{~h}$ at 100 and $200 \mathrm{nmol} / \mathrm{L}$. As shown in Figure 1B, the percentage of cells undergoing DNA replication in $S$ phase was $47.3 \%$ in the control cells and $21.13 \%$ and $9.65 \%$, respectively, in the treated cells, with concomitant increases in the percentage of the $\mathrm{G}_{0} / \mathrm{G}_{1}$ population from $47.3 \%$ to 73.41 and $86.3 \%$, respectively. These results show that BIIB021 inhibits Molt- 4 cell proliferation by causing the accumulation of cells with a $\mathrm{G}_{1}$ DNA content.

\section{BIIB021 induces Molt-4 apoptosis}

We next performed dual staining of the cells with Annexin $\mathrm{V}$ and PI, followed by an analysis using flow cytometry to determine whether BIIB021 exposure could induce apoptosis. The results of Annexin $\mathrm{V}$ staining showed that externalized PS, a characteristic of early apoptosis, was increased in the BIIB021-treated Molt-4 cells in a dose-dependent fashion (Figure 1C). Furthermore, a Western blot analysis showed that
BIIB021 triggered a dose-dependent cleavage of caspase-8, -9, -3 , and poly ADP ribose polymerase (PARP) (Figure 1D). The BIIB021-induced apoptosis was partially inhibited by z-IETDfmk (a caspase-8 inhibitor); conversely, LEHD-fmk (a caspase-9 inhibitor) did not significantly block BIIB021-induced apoptosis in the Molt-4 cells (Figure 1E), suggesting that caspase activation is involved in the induction of apoptosis after BIIB021 treatment.

Effects of BIIB021 on CDK4/6, Akt, p65, p53, and MDM2 expression

By inhibiting Hsp90, an Hsp90 inhibitor can cause the degradation of oncogenic client proteins, including CDK4 and $\mathrm{Akt}^{[24]}$, and these effects may account for the induction of $\mathrm{G}_{1}$ phase arrest. In addition, p18 has been shown to act as a tumor suppressor and selectively inhibit CDK4/6 $6^{[25]}$. To evaluate these effects in the present study, immunoblot assays of Molt- 4 cell extracts were performed to assess CDK4/6, cyclinD1, and p18 expression (Figure 2A). BIIB021 significantly inhibited CDK4/6 expression, whereas cyclinD1, a main component of cyclin D1/CDK complexes, was resistant to BIIB021, with no decrease in expression even at the highest dose (400 nmol/L). Significantly upregulated expression of p18, a CDK inhibitor, was observed in the BIIB021-treated Molt-4 compared to the untreated cells.

It has been reported that Akt signaling is upregulated in T-ALL via the transcriptional repression of PTEN ${ }^{[26]}$. Our data showed that BIIB021 could inhibit Akt protein expression and phosphorylation. Additionally, BIIB021 had a modest effect on p65 expression, a transcription factor of the NF- $\mathrm{kB}$ family (Figure 2B), consistent with a previous report that BIIB021 inhibits constitutive NF- $\mathrm{B}$ activity in Hodgkin's lymphoma cells $^{[11]}$. Interestingly, dose-dependent decreases in the total MDM2 and phospho-MDM2 protein levels in the BIIB021treated cells were observed by Western blotting. Furthermore, a slight upregulation of the total p53 protein and phosphop53 levels occurred concomitantly (Figire 2B). To investigate whether BIIB021 inhibits MDM2 at the transcriptional level, we treated Molt- 4 cells with the agents at $400 \mathrm{nmol} / \mathrm{L}$; quantitative RT-PCR revealed that the mRNA level of MDM2 was significantly inhibited in a time-dependent manner (Figure 2C).

The combination of BIIB021 and TPL selectively enhances antileukemia efficacy in T-ALL

As previous studies have reported p53 upregulation by TPL in cancers ${ }^{[27,28]}$ and we observed the inhibition of MDM2 by BIIB021 in our experiments, we examined whether the sensitivity of Molt- 4 cells to TPL could be enhanced by BIIB021. Molt- 4 cells were treated for $24 \mathrm{~h}$ with various concentrations of TPL and BIIB021 either alone or in combination, and cell viability was determined by an MTT assay. As illustrated in Figure 3A, significant synergy was achieved by the combination treatment of TPL and BIIB021. We next evaluated morphological changes of the T-ALL cells after TPL and BIIB021 treatment alone or in combination using Hoechst33258 stain- 

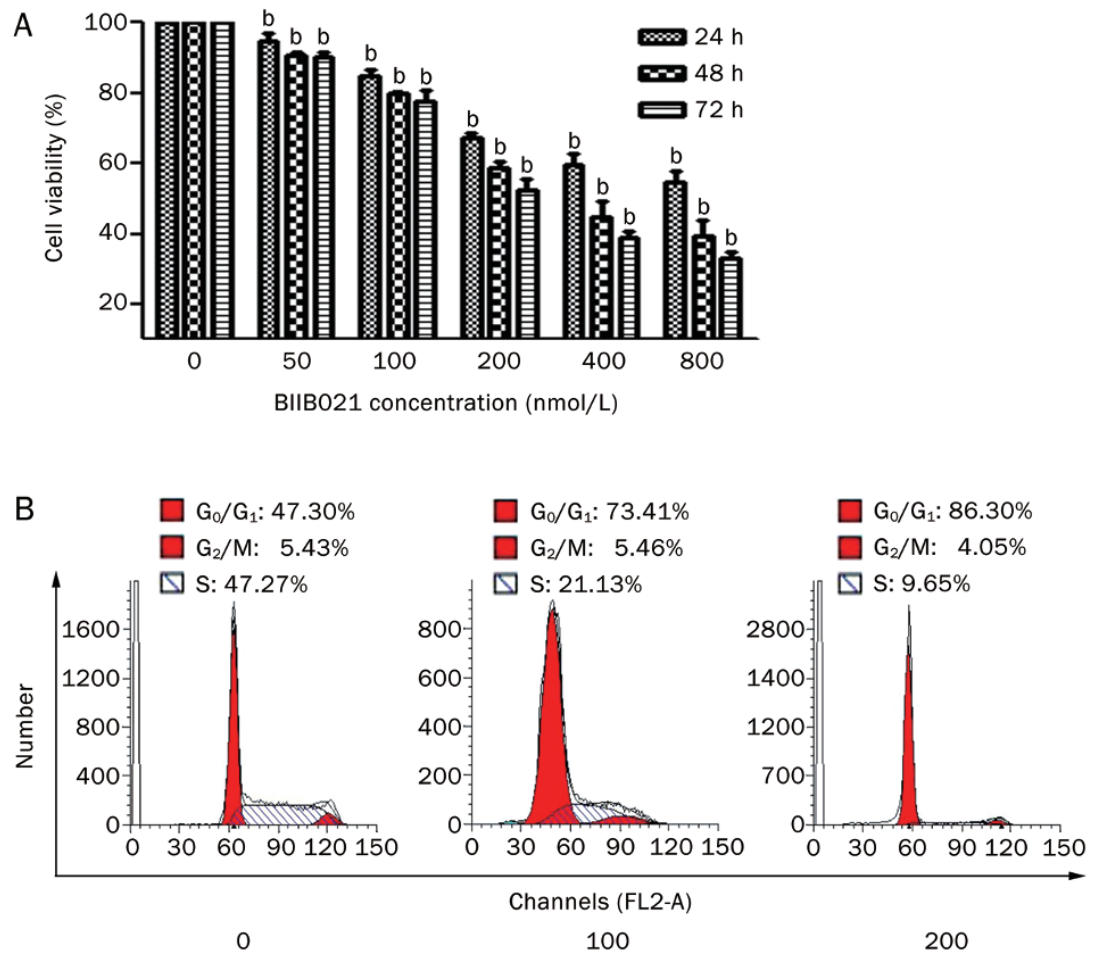

BlIB021 concentration ( $\mathrm{nmol} / \mathrm{L})$
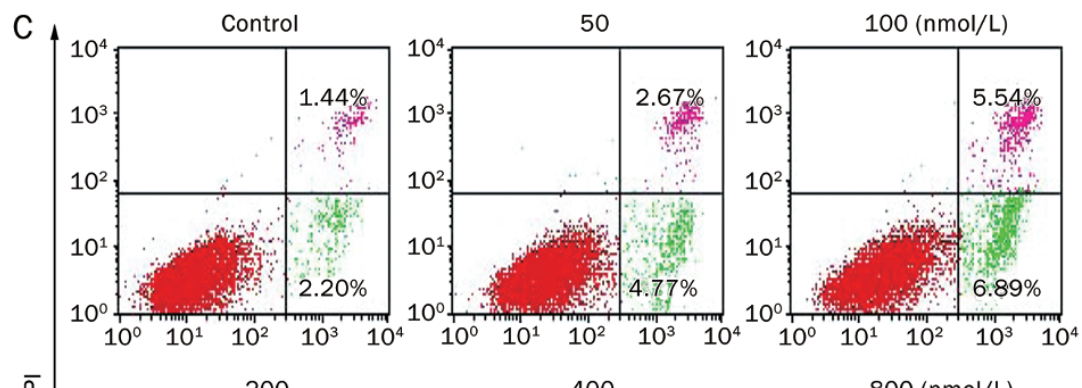

$\bar{\alpha}$
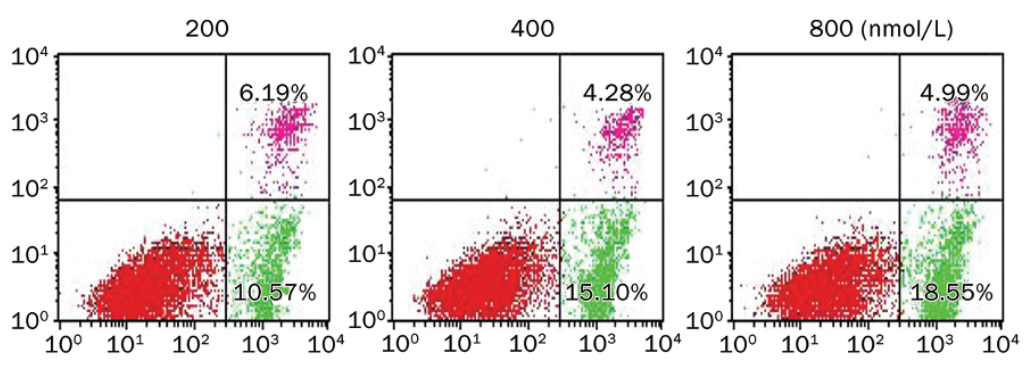

Annexin V-FITC
D

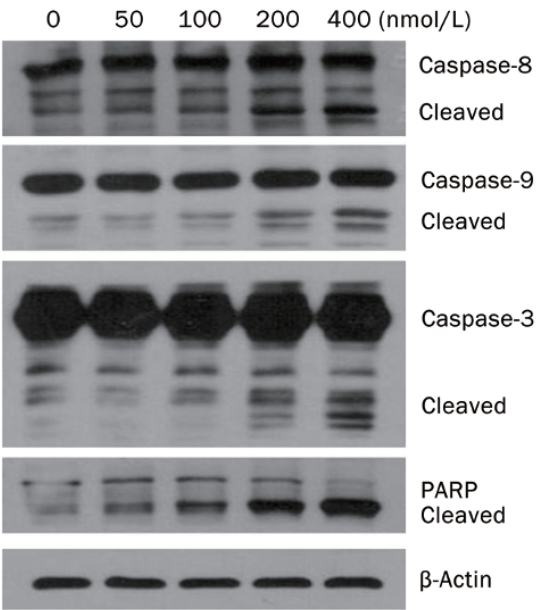

Figure 1. BllB021 inhibits cellular proliferation and induces apoptosis in Molt-4 cells. (A) Molt-4 cells were cultured with or without varying concentrations of BIIB021 in 96-well plates for 24,48 , and $72 \mathrm{~h}$, respectively. The antiproliferative effects were measured by the MTT assay. (B) The cells were treated with BIIB021 at $100 \mathrm{nmol} / \mathrm{L}$ and $200 \mathrm{nmol} / \mathrm{L}$ for $24 \mathrm{~h}$ and stained with PI. The DNA content was analyzed by flow cytometry. (C) Molt-4 cells were treated with BIIB021 at the indicated doses for $24 \mathrm{~h}$, and apoptosis was assessed by flow cytometry using Annexin V/PI staining. (D) The cleavage of caspases and poly (ADP-ribose) polymerase (PARP) was examined by Western blot analyses of Molt- 4 whole-cell lysates after treatment with various concentrations of BIIB021 for $24 \mathrm{~h}$. Representative data are shown. (E) Molt-4 cells were treated with BIIB021 (800 nmol/L for $24 \mathrm{~h}$ ), with or without pretreatment with Z-IETD-fmk $(10 \mu \mathrm{mol} / \mathrm{L})$ or Z-LEHD-fmk $(10 \mu \mathrm{mol} / \mathrm{L})$. The induction of apoptosis was determined by flow cytometry. The values represent the mean $\pm \mathrm{SD}$ for 3 independent experiments. ${ }^{\mathrm{b}} P<0.05$ compared with Con group. ${ }^{\mathrm{d}} P>0.05,{ }^{\mathrm{e}} P<0.05$ compared with BIIB021 group.

ing. The results showed that the combined treatment of Molt-4 cells with TPL $(20 \mathrm{nmol} / \mathrm{L})$ and BIIB021 (100 nmol/L) resulted in extensive chromosome condensation and nuclear shrinkage and/or fragmentation (Figure 3B), all of which are hallmarks of apoptosis.

Apoptosis was also quantified using a PI staining assay and 
A

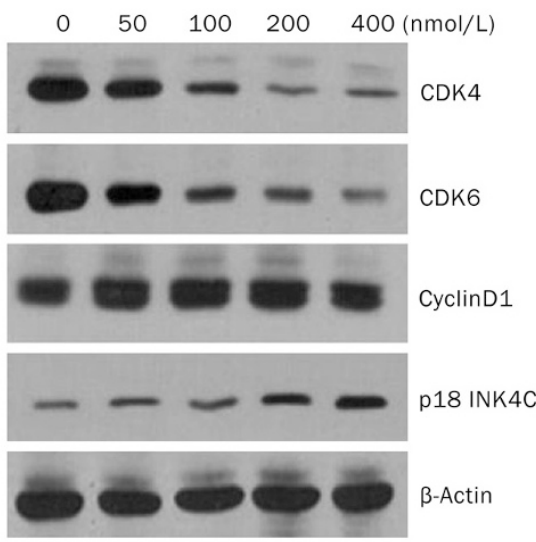

B
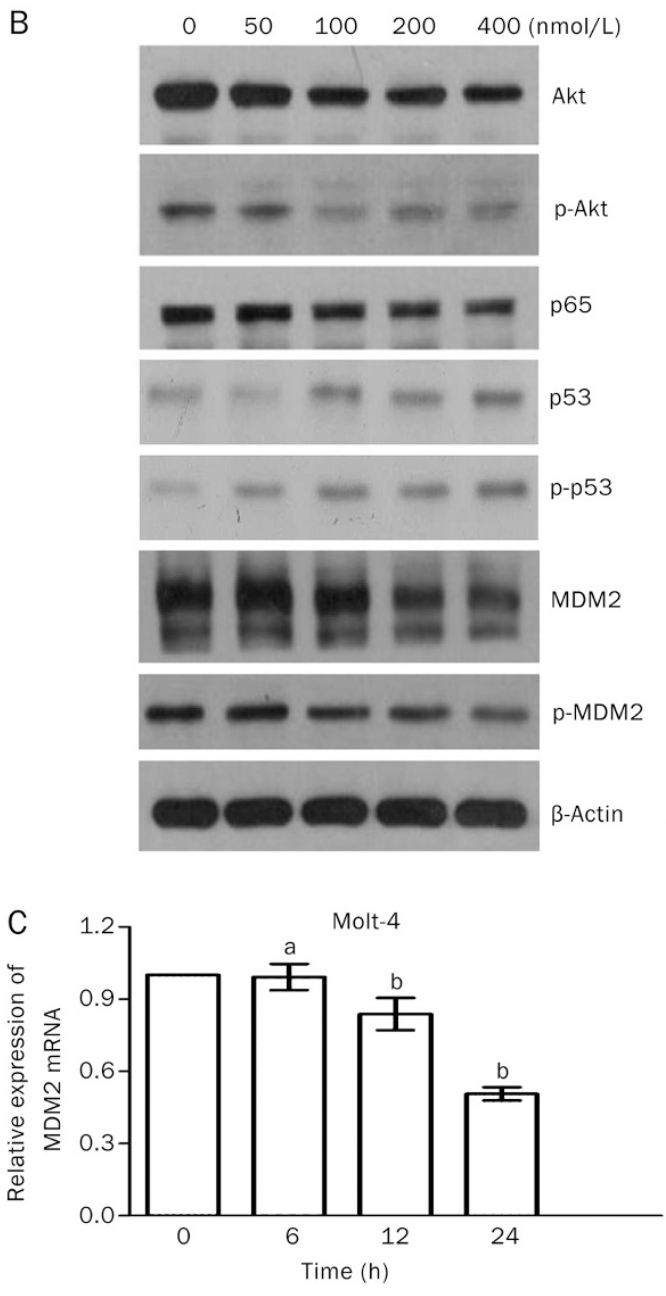

Figure 2. Effects of BllB021 on growth and survival signaling pathways. (A) Molt-4 cells were treated with BIIB021 at the indicated doses for $24 \mathrm{~h}$. Whole-cell lysates (15 $\mu \mathrm{g}$ of protein per lane) were prepared to assess the levels of CDK4, CDK6, cyclinD1, and p18 INK4C. (B) Molt-4 cells were treated with BIIB021 (0, 50, 100, 200, and $400 \mathrm{nmol} / \mathrm{L})$. Total proteins were extracted and subjected to Western blotting using specific antibodies against Akt, phospho-Akt, p65, p53, phospho-p53, MDM2, and phosphoMDM2. (C) Molt-4 cells were treated with $400 \mathrm{nmol} / \mathrm{L}$ BIIB021 for 6, 12, and $24 \mathrm{~h}$, and the MDM2 mRNA levels were determined by quantitative real-time PCR. The relative changes in gene expression are shown compared to the untreated controls. The values represent the mean $\pm S D$ for 3 independent experiments. ${ }^{\mathrm{a}} \mathrm{P}>0.05,{ }^{\mathrm{b}} \mathrm{P}<0.05$ compared with Con group.
Annexin $\mathrm{V}$ binding. As shown in Figure 3C, the combination treatment elicited $42 \%$ of Molt -4 cells to undergo apoptosis, whereas treatment with TPL and BIIB021 alone resulted in $20.2 \%$ and $8.7 \%$ apoptotic cells, respectively. To determine whether treatment with TPL and BIIB021 affects the caspase cascade, we analyzed the leukemic cells for these molecular markers. Molt- 4 cells treated with TPL or BIIB021 alone showed a weak cleavage of caspase- $9,-8,-3$, and PARP, which are indicators of caspase cascade activation. In contrast, an enhanced expression of cleaved caspase-9, -8, -3, and PARP was observed in the cells treated with the combination therapy (Figure 3D). Altogether, these findings demonstrate that the synergistic effect of TPL and BIIB021 occurs via apoptosis.

To assess the cytotoxic effects of TPL, BIIB021, or their combination on normal cells, we treated L-02 cells, a human liver cell line, with TPL ( $40 \mathrm{nmol} / \mathrm{L})$, BIIB021 ( $200 \mathrm{nmol} / \mathrm{L})$, or both for $48 \mathrm{~h}$ and assessed cell viability by an MTT assay. TPL or BIIB021 alone exhibited slight cytotoxic effects on the L-02 cells; furthermore, cytotoxicity in the normal cells was not significantly increased by the combination of TPL and BIIB021 (Figure 3E).

\section{Mechanisms of enhanced apoptosis induced by BIIB021 and TPL co-treatment}

To investigate the potential molecular mechanisms of the sensitization of T-ALL cells to TPL by BIIB021, we examined alterations in the expression of MDM2 and p53 in Molt-4 cells after treatment with TPL and BIIB021 alone or in combination. TPL upregulated the levels of total p53 and phospho-p53 in a dose-dependent manner but did not affect the expression of MDM2 (Figure 4A). Importantly, the co-exposure of Molt-4 cells to TPL and BIIB021 resulted in increases in p53 protein and phospho-p53 expression (Figure 4B). We also examined Bcl-2 family members, including the pro-apoptotic proteins Bid, Bak, Bim, Bax, and Bad and anti-apoptotic proteins Bcl$\mathrm{xL}, \mathrm{Bcl}-2$, and Mcl-1 (Figure 4B). Although there were no detectable modulations of Bcl-xL, Bax, and Bad, TPL inhibited Mcl-1 expression and induced the expression of Bak and Bim, whereas BIIB021 upregulated Bak and Bim and downregulated Bcl-2. In addition, the expression of Bid was downregulated by TPL, suggesting the cleavage of Bid. Furthermore, the combination therapy of TPL and BIIB021 resulted in a synergistic upregulation of Bak and Bim.

\section{Discussion}

The extrinsic and intrinsic apoptotic pathways are regulated by multiple proteins, such as those involved in the p53, NF- $\mathrm{kB}$, and PI3K/Akt signaling pathways. Unlike the situation in solid tumors, mutation of the TP53 gene is infrequent in ALL, at less than $3 \%{ }^{[29]}$. Additionally, there is a low percentage of TP53 mutation in T-ALL patients at diagnosis ${ }^{[30,31]}$, which increases upon relapse ${ }^{[32-34]}$. However, a recent study suggests that the TP53 pathway is inactivated by epigenetic mechanisms in the majority of ALL patients ${ }^{[35]}$. In addition, MDM2, a negative cellular regulator of p53, is frequently overexpressed in $\mathrm{ALL}^{[36]}$, and it has been recently well demonstrated 
A
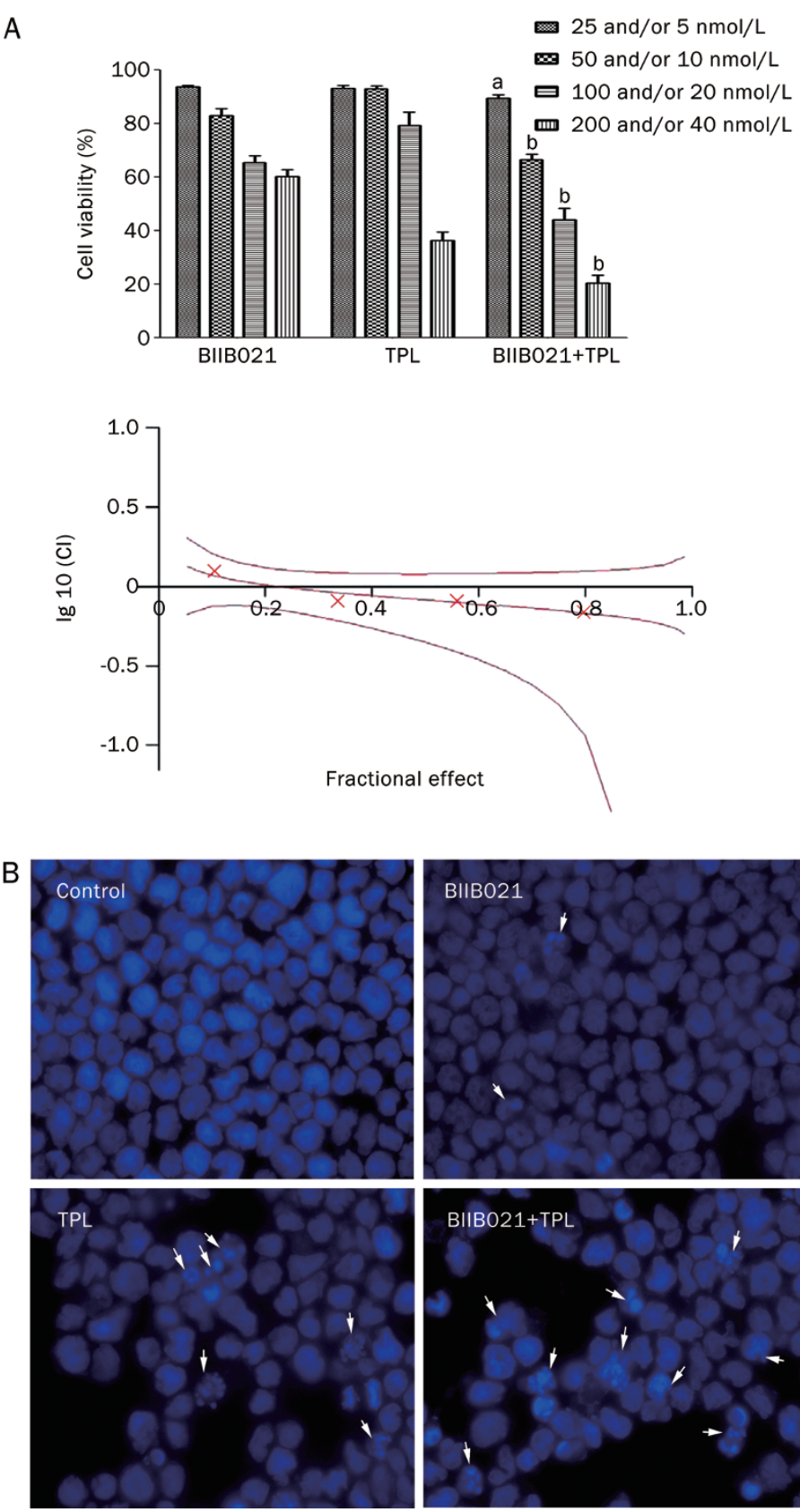
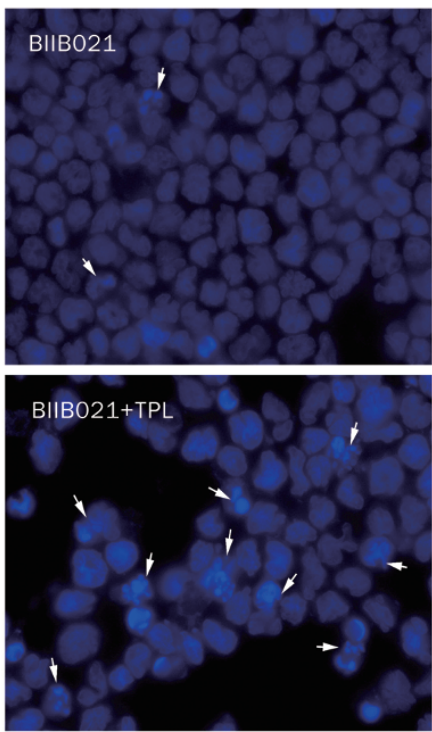

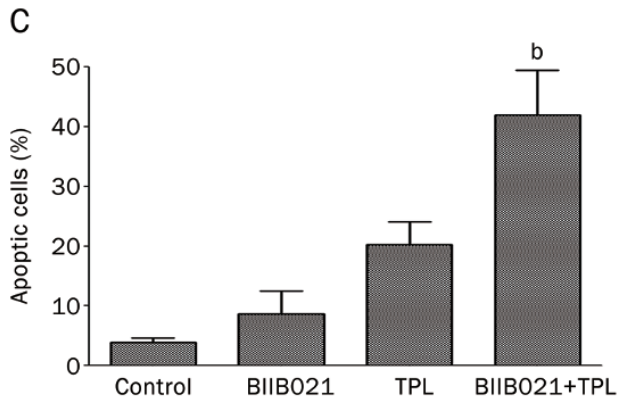

D

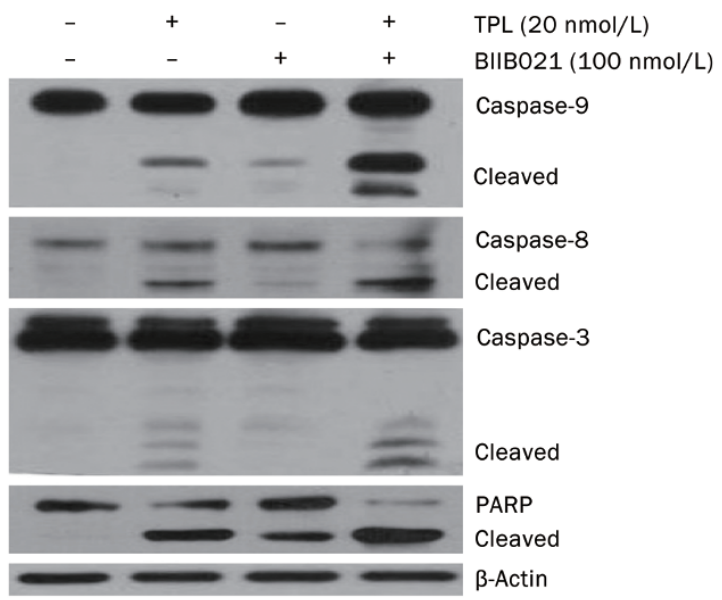

E

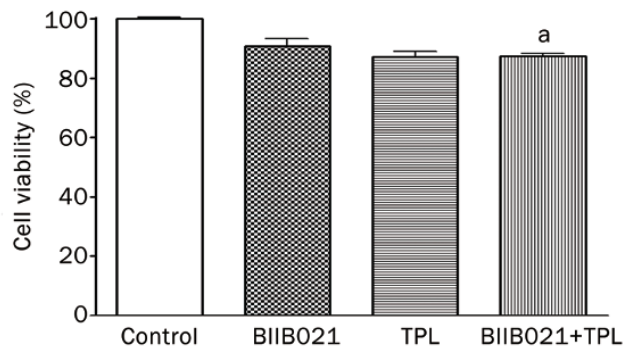

Figure 3. Synergistic cytotoxicity to Molt-4 cells of BIIB021 in combination with TPL. (A) Molt-4 cells were treated with BIIB021 ( $25,50,100$, and 200 $\mathrm{nmol} / \mathrm{L})$, TPL ( $5,10,20$, and $40 \mathrm{nmol} / \mathrm{L})$, or BIIB021 plus TPL for $24 \mathrm{~h}$, and viability was assessed using the MTT assay. The combination index values were calculated as described in Materials and methods. (B)The leukemic cells were incubated with BIIB021 (100 nmol/L), TPL (20 nmol/L), or BIIB021 plus TPL for $24 \mathrm{~h}$ and stained with Hoechst 33258. The arrow indicates an apoptotic cell. (C) A quantitative analysis of apoptosis was performed in Molt-4 cells treated with BIIB021 (100 nmol/L), TPL (20 nmol/L), or BIIB021 combined with TPL for $24 \mathrm{~h}$ using Annexin V/PI staining, followed by flow cytometry. (D) Molt-4 cells were treated with BIIB021, TPL, or BIIB021 combined with TPL at the indicated doses for $24 \mathrm{~h}$, and the activation of caspases and PARP was analyzed by immunoblotting. B-Actin was used as a loading control. (E) L-02 cells, a human normal liver cell line, were grown in a 96-well plate and treated with BIIB021 $(200 \mathrm{nmol} / \mathrm{L})$, TPL $(40 \mathrm{nmol} / \mathrm{L})$, or in combination for $48 \mathrm{~h}$. Cell viability was assessed by the MTT assay. One-way analysis of variance. ${ }^{\mathrm{a} P}>0.05,{ }^{\mathrm{b}} \mathrm{P}<0.05$ compared to either single agent alone.

that disruption of the p53-MDM2 interaction through MDM2 inhibition results in the elevation of p53 protein levels, followed by p53-mediated apoptosis ${ }^{[37,38]}$. Thus, the disruption of the p53-MDM2 interaction represents a promising targeted approach to treat T-ALL with wild-type p53. In this study, we found that BIIB021 significantly inhibited the levels of total MDM2 and phospho-MDM2 in wild-type p53 Molt-4 cells in a dose-dependent manner. Additionally, we demonstrated the downregulation of MDM2 mRNA expression in Molt-4 cells after treatment with BIIB021. 


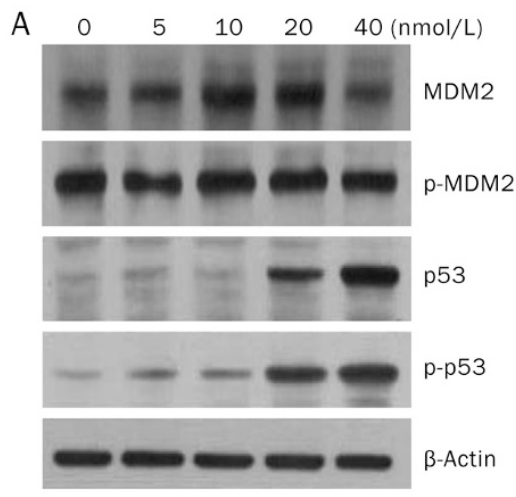

B

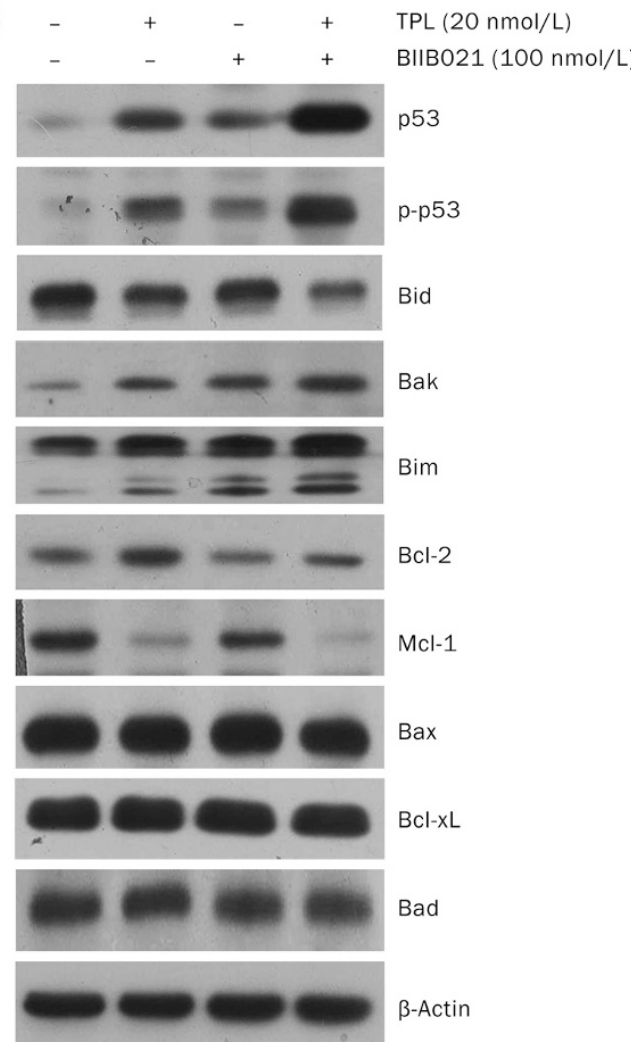

Figure 4. Combination treatment with BIIB021 and TPL activates p53 protein expression and regulates the expression of $\mathrm{Bcl}-2$ family proteins. (A) The protein levels of p53, MDM2, and phospho-p53 and -MDM2 were evaluated by immunoblot using the extracts of Molt- 4 cells incubated with TPL at the indicated doses for $24 \mathrm{~h}$. (B) Molt- 4 cells were treated with TPL (20 nmol/L) and BIIB021 (100 nmol/L) alone or in combination. The expression of $\mathrm{p} 53$ and $\mathrm{Bcl}-2$ family proteins at $24 \mathrm{~h}$ was determined by Western blotting.

Considering that TPL activates p53 without influencing MDM2 levels, we hypothesized that BIIB021 may sensitize T-ALL cells to TPL-mediated apoptosis. We discovered that BIIB021 significantly synergized the antileukemic effect of $\mathrm{TPL}$, with the concomitant upregulation of p53. The $\mathrm{IC}_{50}$ values of BIIB021 in various solid tumors were reported to be $60-310 \mathrm{nmol} / \mathrm{L}^{[10]}$. However, our data showed that Molt-4 cells were less sensitive to BIIB021 than solid tumor cells, with $\mathrm{IC}_{50}$ values of 384.6 and $301.8 \mathrm{nmol} / \mathrm{L}$ at $48 \mathrm{~h}$ and $72 \mathrm{~h}$, respectively. Interestingly, up to $42 \%$ of the leukemic cells were apoptotic cells after treatment with BIIB021 (100 nmol/L) plus TPL ( $20 \mathrm{nmol} / \mathrm{L})$, whereas the cells treated with BIIB021 or TPL alone at the same doses showed only $8.7 \%$ and $20.2 \%$ apoptosis, respectively, suggesting significantly enhanced cell death due to the combination of low-dose BIIB021 with TPL.

It is well known that Hsp90 inhibitors induce the degradation of Akt, an Hsp90 client protein, and that the activation of Akt suppresses caspase- 9 . We observed decreases in the Akt levels and cleavage of Bid by BIIB021, followed by the activation of caspase-9. BIIB021 also activated caspase-8 in Molt-4 cells, consistent with the findings of a previous study ${ }^{[39]}$. Additionally, TPL has been shown to induce the loss of mitochondrial membrane potential and cytochrome $c$ release, whereas caspase-9 knockout cells are resistant to TPL ${ }^{[16]}$. We showed that TPL inhibited Mcl-1 expression and induced the expression of Bak and Bim, though BIIB021 upregulated Bak and Bim and downregulated Bcl-2. These pro-apoptotic and anti-apoptotic proteins play key roles in the mitochondriadependent pathway of apoptosis. Consistent with these findings, the combination therapy of BIIB021 and TPL elicited a synergistic effect in the modulation of Bak and Bim, followed by a strong activation of caspase- 9 and cleavage of caspase- 3 and PARP. Therefore, the two main pathways of procaspase activation (the intrinsic mitochondrial pathway and extrinsic death receptor pathway) are involved in the combination treatment-induced apoptosis.

In summary, we found that BIIB021 induces cytotoxicity in the T-ALL cell line Molt-4 in vitro via mechanisms that are related to cell cycle arrest and the induction of apoptosis. In addition, BIIB021 significantly inhibited the levels of phosphoMDM2 and total MDM2 and sensitized the Molt-4 cells to TPL-induced cell death through the disruption of the p53MDM2 interaction and the activation of p53. This combined effect is also regulated by multiple pathways, including those involving Akt and Bcl-2 family proteins (Figure 5). These factors serve as potential targets for future T-ALL therapy.

\section{Acknowledgements}

This work was supported by the Doctoral Fund of Ministry of Education of China (№ 20120101110010), National Natural Science Foundation of China grants (№ 81070419 and № 81200384), Zhejiang Provincial Natural Science Foundation of China (№ R2090392), Funds of Science Technology Department of Zhejiang Province (№ 2012C13021-2 and № 2012C37103), and Fund of Health Bureau of Zhejiang Province (№ 2010SSA006).

\section{Author contribution}

Wen-bin QIAN designed the research project; Min LI, Xiang ZHANG, Wen-jing ZHOU, Yue-hua CHEN, Hui LIU, Lin LIU, and Chun-mei YANG performed research; Wen-bin QIAN and Min LI analyzed the data; Wen-bin QIAN, Xiang ZHANG, and Wen-jing ZHOU wrote the manuscript. 


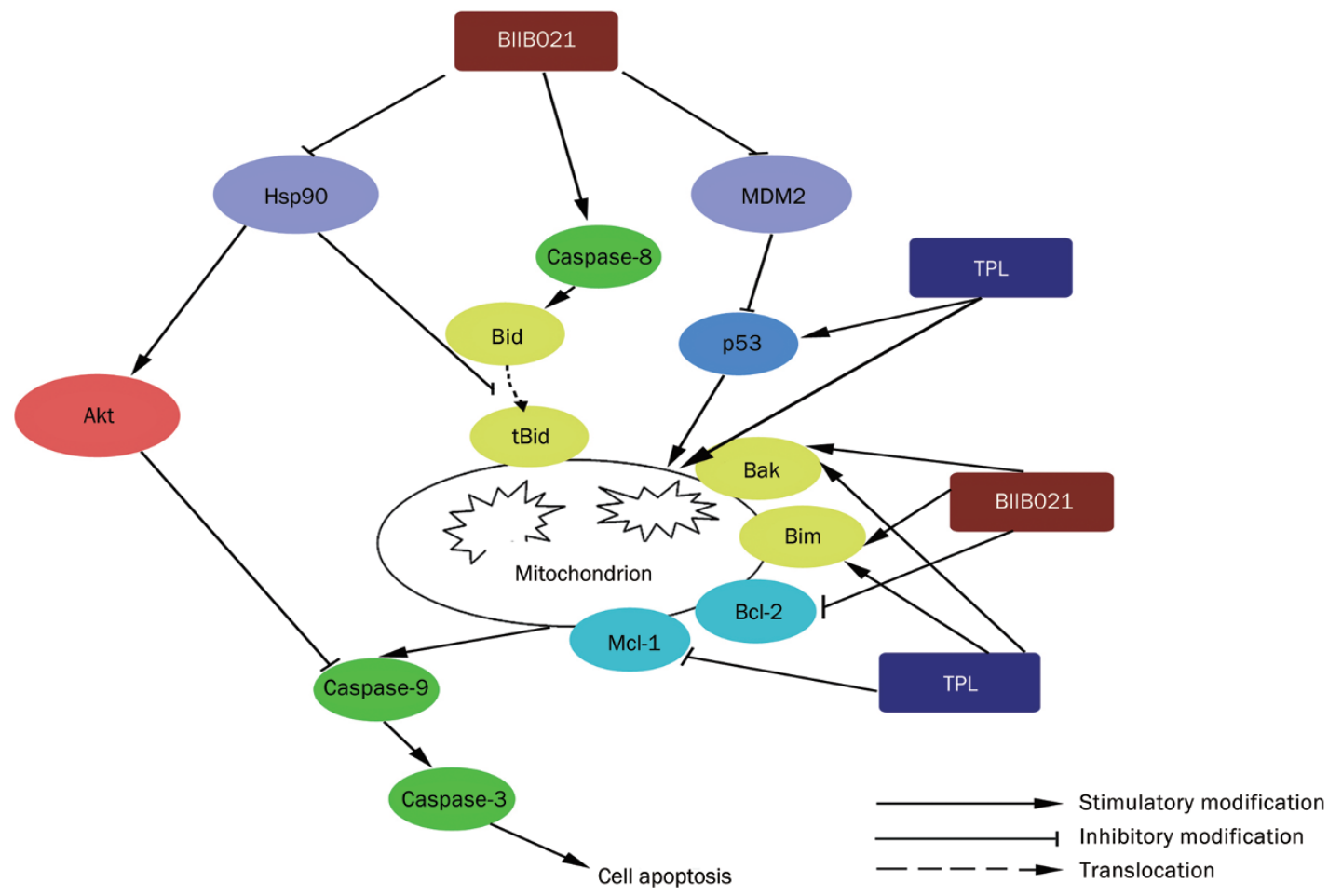

Figure 5. Schematic representation of the molecules involved in the combination therapy of BIIB021 and TPL.

\section{References}

1 Ferrando AA, Neuberg DS, Staunton J, Loh ML, Huard C, Raimondi SC, et al. Gene expression signatures define novel oncogenic pathways in T cell acute lymphoblastic leukemia. Cancer Cell 2002; 1: 75-87.

2 Pui CH, Robison LL, Look AT. Acute lymphoblastic leukaemia. Lancet 2008; 371: 1030-43.

3 Xiao K, Liu W, Qu S, Sun H, Tang J. Study of heat shock protein HSP90 alpha, HSP70, HSP27 mRNA expression in human acute leukemia cells. J Tongji Med Univ 1996; 16: 212-6.

4 Lauten M, Beger C, Gerdes K, Asgedom G, Kardinal C, Welte K, et al. Expression of heat-shock protein 90 in glucocorticoid-sensitive and -resistant childhood acute lymphoblastic leukaemia. Leukaemia 2003; 17: 1551-6.

5 Hacıhanefioglu A, Gonullu E, Mehtap O, Keski H, Yavuz M, Ercin C. Effect of heat shock protein-90 (HSP90) and vascular endothelial growth factor (VEGF) on survival in acute lymphoblastic leukemia: an immunohistochemical study. Med Oncol 2011; 28: 846-51.

6 Tong WG, Estrov Z, Wang Y, O'Brien S, Faderl S, Harris DM, et al. The synthetic heat shock protein 90 (Hsp90) inhibitor EC141 induces degradation of Bcr-Abl p190 protein and apoptosis of Ph-positive acute lymphoblastic leukemia cells. Invest New Drugs 2011; 29 : 1206-12.

7 Tavernier E, Flandrin-Gresta P, Solly F, Rigollet L, Cornillon J, AugeulMeunier K, et al. HSP9O inhibition results in apoptosis of Philadelphia acute lymphoblastic leukaemia cells: an attractive prospect of new targeted agents. J Cancer Res Clin Oncol 2012; 138: 1753-8.

8 Peng C, Li D, Li S. Heat shock protein 90: a potential therapeutic target in leukemic progenitor and stem cells harboring mutant BCRABL resistant to kinase inhibitors. Cell Cycle 2007; 6: 2227-31.

9 Taldone T, Gozman A, Maharaj R, Chiosis G. Targeting Hsp90: small-molecule inhibitors and their clinical development. Curr Opin
Pharmacol 2008; 8: 370-4.

10 Lundgren $\mathrm{K}$, Zhang $\mathrm{H}$, Brekken J, Huser N, Powell RE, Timple N, et al. BIIB021, an orally available, fully synthetic small-molecule inhibitor of the heat shock protein Hsp90. Mol Cancer Ther 2009; 8: 921-9.

11 Böll B, Eltaib F, Reiners KS, von Tresckow B, Tawadros S, Simhadri VR, et al. Heat shock protein 90 inhibitor BIIB021 (CNF2024) depletes NF-kappaB and sensitizes Hodgkin's lymphoma cells for natural killer cell-mediated cytotoxicity. Clin Cancer Res 2009; 15: 5108-16.

12 Yin X, Zhang H, Lundgren K, Wilson L, Burrows F, Shores CG. BIIB021, a novel Hsp90 inhibitor, sensitizes head and neck squamous cell carcinoma to radiotherapy. Int J Cancer 2010; 126: 1216-25.

13 Zhang H, Neely L, Lundgren K, Yang YC, Lough R, Timple N, et al. BIIB021, a synthetic Hsp90 inhibitor, has broad application against tumors with acquired multidrug resistance. Int J Cancer 2010; 126: 1226-34.

14 Dickson MA, Okuno SH, Keohan ML, Maki RG, D'Adamo DR, Akhurst TJ, et al. Phase Il study of the HSP90-inhibitor BIIB021 in gastrointestinal stromal tumors. Ann Oncol 2013; 24: 252-7.

15 Luo Y, Shi C, Liao M. Advance in the anti-tumor mechanism of triptolide. Chin J Chin Mater Med 2009; 34: 2024-6.

16 Carter BZ, Mak DH, Schober WD, McQueen T, Harris D, Estrov Z, et al. Triptolide induces caspase-dependent cell death mediated via the mitochondrial pathway in leukemic cells. Blood 2006; 108: 630-7.

17 Carter BZ, Mak DH, Schober WD, Dietrich MF, Pinilla C, Vassilev LT, et al. Triptolide sensitizes AML cells to TRAlL-induced apoptosis via decrease of XIAP and P53-mediated increase of DR5. Blood 2008; 111: 3742-50.

18 Park B, Sung B, Yadav VR, Chaturvedi MM, Aggarwal BB. Triptolide, histone acetyltransferase inhibitor, suppresses growth and chemosensitizes leukemic cells through inhibition of gene expression regulated by TNF-TNFR1-TRADD-TRAF2-NIK-TAK1-IKK pathway. 
Biochem Pharmacol 2011; 82: 1134-44.

19 Li H, Hui L, Xu W, Shen H, Chen Q, Long L, et al. Triptolide modulates the sensitivity of K562/A02 cells to adriamycin by regulating miR-21 expression. Pharm Biol 2012; 50: 1233-40.

20 Li H, Hui L, Xu W, Shen H, Chen Q, Long L, et al. Modulation of P-glycoprotein expression by triptolide in adriamycin-resistant K562/ A02 cells. Oncol Lett 2012; 3: 485-9.

21 Zhou GS, Hu Z, Fang HT, Zhang FX, Pan XF, Chen XQ, et al. Biologic activity of triptolide in $t(8 ; 21)$ acute myeloid leukemia cells. Leuk Res 2011; 35: 214-8.

22 Huang $M$, Zhang $H$, Liu T, Tian D, Gu L, Zhou M. Triptolide inhibits MDM2 and induces apoptosis in acute lymphoblastic leukemia cells through a P53-independent pathway. Mol Cancer Ther 2013; 12: 184-94.

23 Meng HT, Zhu L, Ni WM, You LS, Jin J, Qian WB. Triptolide inhibits the proliferation of cells from lymphocytic leukemic cell lines in association with downregulation of NF-KB activity and miR-16-1*. Acta Pharmacol Sin 2011; 32: 503-11.

24 Bai F, Pei XH, Godfrey VL, Xiong Y. Haploinsufficiency of p18 (INK4c) sensitizes mice to carcinogen-induced tumorigenesis. Mol Cell Biol 2003; 23: 1269-77.

25 Powers MV, Workman P. Targeting of multiple signalling pathways by heat shock protein 90 molecular chaperone inhibitors. Endocr Relat Cancer 2006; 13: S125-35.

26 Palomero T, Sulis ML, Cortina M, Real PJ, Barnes K, Ciofani M, et al. Mutational loss of PTEN induces resistance to NOTCH1 inhibition in T-cell leukemia. Nat Med 2007; 13: 1203-10.

27 Chang WT, Kang JJ, Lee KY, Wei K, Anderson E, Gotmare S, et al. Triptolideand chemotherapy cooperate in tumor cell apoptosis. A role for the p53 pathway. J Biol Chem 2001; 276: 2221-7.

28 Jiang $\mathrm{XH}$, Wong BC, Lin MC, Zhu GH, Kung HF, Jiang SH, et al. Functional p53 is required for triptolide-induced apoptosis and AP-1 and nuclear factor-kappaB activation in gastric cancer cells. Oncogene 2001; 20: 8009-18.

29 Agirre X, Novo FJ, Calasanz MJ, Larráyoz MJ, Lahortiga I, Valgañón $\mathrm{M}$, et al. TP53 is frequently altered by methylation, mutation, and/or deletion in acute lymphoblastic leukaemia. Mol Carcinog 2003; 38: 201-8.

30 Jonveaux P, Berger R. Infrequent mutations in the P53 gene in primary human T-cell acute lymphoblastic leukemia. Leukemia 1991; 5: 839-40.

31 Yeargin J, Cheng J, Haas M. Role of the p53 tumor suppressor gene in the pathogenesis and in the suppression of acute lymphoblastic T-cell leukemia. Leukemia 1992; 6: 85S-91S.

32 Diccianni MB, Yu J, Hsiao M, Mukherjee S, Shao LE, Yu AL. Clinical significance of p53 mutations in relapsed T-cell acute lymphoblastic leukemia. Blood 1994; 84: 3105-12.

33 Hsiao MH, Yu AL, Yeargin J, Ku D, Haas M. Nonhereditary p53 mutations in T-cell acute lymphoblastic leukemia are associated with the relapse phase. Blood 1994; 83: 2922-30.

34 Kawamura M, Ohnishi H, Guo SX, Sheng XM, Minegishi M, Hanada $\mathrm{R}$, et al. Alterations of the p53, p21, p16, p15, and RAS genes in childhood T-cell acute lymphoblastic leukemia. Leuk Res 1999; 23: 115-26.

35 Vilas-Zornoza A, Agirre X, Martín-Palanco V, Martín-Subero JI, San José-Eneriz E, Garate L, et al. Frequent and simultaneous epigenetic inactivation of TP53 pathway genes in acute lymphoblastic leukemia. PLoS One 2011; 6: e17012.

36 Hendy OM , Elghannam DM , El-Sharnouby JA , Goda EF, El-Ashry R, AlTonbary $Y$. Frequency and prognostic significance of murine double minute protein-2 overexpression and p53 gene mutations in childhood acute lymphoblastic leukemia. Hematology 2009; 14: 335-40.

37 Wade M, Li YC, Wahl GM. MDM2, MDMX and p53 in oncogenesis and cancer therapy. Nat Rev Cancer 2012; 13: 83-96.

$38 \mathrm{Li}$ Q, Lozano G. Molecular pathways: targeting Mdm2 and Mdm4 in cancer therapy. Clin Cancer Res 2013; 19: 34-41.

39 Lamottke B, Kaiser M, Mieth M, Heider U, Gao Z, Nikolova Z, et al. The novel, orally bioavailable HSP90 inhibitor NVP-HSP990 induces cell cycle arrest and apoptosis in multiple myeloma cells and acts synergistically with melphalan by increased cleavage of caspases. Eur J Haematol 2012; 88: 406-15. 